\title{
Karyotypic studies of the genus Cuscuta L. (Convolvulaceae) in Saudi Arabia and their taxonomic significance
}

\section{Sherif M. Sharawy}

Botany Department, Faculty of Science, Ain Shams University, Cairo, Egypt

Sherif M. Sharawy, 2013. Karyotypic studies of the genus Cuscuta L. (Convolvulaceae) in Saudi Arabia and their taxonomic significance. Taeckholmia 33: 65-82.

$C_{\text {hromosome numbers and karyotype criteria of nine }}$ species of the genus Cuscuta L. (Convolvulaceae) in Saudi Arabia were investigated. Chromosomes counts were recorded in four species for the first time in this study. Chromosome number, based on $\mathrm{x}=7$ has been found in the majority of the studied Cuscuta species. A diploid number $(2 n=14)$ was recorded in five species, while tetraploid number $(2 n=28)$ was recorded in two species whereas $2 n=56$ was recorded in C. campestris. However, $2 \mathrm{n}=30$ based on $\mathrm{x}=6$ was recorded in $C$. monogyna. The chromosomes in the studied species of Cuscuta are generally small with a mean size ranging between 0.74 and $1.10 \mu \mathrm{m}$. Short chromosomes were particularly found in $C$. planiflora $(\mathrm{MCL}=0.74 \mu \mathrm{m})$ and C. chinesis $(\mathrm{MCL}=0.79)$, whereas longer chromosomes were scored in $C$. campestris $(\mathrm{MCL}=1.10)$. The karyotype in the studied species is mostly comprised of metacentric to submetacentric chromosomes as indicated by their mean arm ratio that ranges between 1.31 in $C$. monogyna and 1.83 in $\mathrm{C}$. planiflora. The degree of karyotype asymmetry is indicated by high values of TF\% ranges between 28.33 in $C$. planiflora and 40.54 in $C$. campestris. The A1 value ranged between 0.22 in C. planiflora and 0.43 in C. palaestina. Among the examined species, karyotype features were used to assess the

Received 7 Feb. 2014, accepted 29 Mar. 2014 
classification of the Cuscuta species in Saudi Arabia in the light of the current systems of classification.

Key words: Karyotype, Cuscuta, Chromosomes, Taxonomy, Saudi Arabia.

\section{Introduction}

The genus Cuscuta L. (dodders) is composed of approximately 200 species of tiny obligatory parasites that grow in a wide variety of climates and ecosystems (Yuncker, 1932; Stefanovic et al., 2007; Welsh et al., 2010 and Costea et al., 2011). All members of this genus are vines with twining, slender, pale stems, with reduced, scale like leaves, and no roots. The parasitic stems are attached to the hosts by haustoria and depend entirely on their hosts to supply water and nutrients (Kujit, 1969; Dawson et al., 1994). Most Cuscuta species are also characterized by reduced amounts or the complete absence of chlorophyll (van der Kooij et al., 2000). Cuscuta is considered economically important because several species can cause significant losses to agricultural crops (Parker and Riches, 1993; Costea and Tardiff, 2006). However, many species are also ecologically important, acting as keystone species in their natural ecosystem (Press and Phoenix, 2005) and some dodders are in need of conservation (Costea and Stefanovic, 2009). Cuscuta is nearly cosmopolitan in distribution with its species found on every continent (except Antractica), ranging from the $60^{\text {th }}$ parallel north in Europe and Asia, to the Cape region of South Africa and as far as south as the $47^{\text {th }}$ parallel in Argentina and Chile (Yuncker, 1932; Hunziker, 1950; Mabberley, 1987 and Stefanovic, et al., 2007). In Saudi Arabia, the number of Cuscuta species increased with time since Migahid (1989) reported the presence of two species. Mandaville (1990) recorded three species while Collenette, (1999) confirmed the presence of nine species.

The genus was nested within Convolvulaceae under the subfamily Cuscutoideae (Engelmann, 1859; Bentham and Hooker, 1862; Bessey, 1915; Core, 1955; Engler, 1964; Hutchinson and Ashton, 1979). Other authors considered the species of the genus into a family of its own viz. Cuscutaceae depending on the mode of nutrition (Hutchinson, 1959; Cronquist, 1968; Hadac and Chrtek, 1970; Willis, 1973; Austin, 1975; Takhtajan, 1980). Engelmann (1859) divided the genus Cuscuta into three groups based primarily on stigma and style morphology. These groups were formally adopted by Peter (1897) and later by Yuncker (1932) as subgenera. 
Subgenera Monogyna (Monogynella) has a single style with a variety of stigma shapes. Subgenera Cuscuta and Grammica are characterized by two distinct styles and can be distinguished by their stigma morphology (elongated and linear vs. short and capitate, respectively). Hadac and Chrtek (1970), on the bases of floral characters, accepted the Cuscutaceae but they added one more subgenus (Kadurias) to Engelmann's sub-genera. Recent molecular data (McNeal et al., 2005; Stefanovic et al., 2007 and Braukmann, et al., 2013), also revealed a fourth major clade, consisting of Cuscuta species native to South Africa.

The importance of chromosomal information in plant systematics has attracted the attention of several authors. At the generic level and below chromosomes features provided a range of possibilities for understanding the affinities of taxa. The classification of a number of families has been either aided or substantiated by information from chromosome criteria or features as for example, chromosome size, the position of the centromere and special banding patterns (Badr and Elkington, 1978; Moore, 1978; Jackson. 1984; Badr and El-Kholy, 1986; Fernandez, et al., 1993; El-Shazly and Abou El-Enain, 1999; Jianquan et al., 2001; Badr and Sharawy, 2007; Sharawy, 2008). Karyotype studies were principally based on the bases that symmetrical karyotypes are more primitive than asymmetrical ones, longer chromosome than shorter ones, median centromeres with chromosome arms of equal length were more primitive than chromosome with arms of unequal length, low basic number has given rise to higher ones (Stebbins, 1956).

The aim of this study is to describe the karyotype criteria for nine species of Cuscuta in Saudi Arabia and discussing the impact of the variation in these criteria on the systematic treatments of the studied species.

\section{Materials and Methods}

The species used in this study are Cuscuta brevistylosa, C. campestris, C. epilinum, C. chinesis, C. hyalina, C. monogyna, C. palaestina, $C$. pedicellata and $C$. planiflora. These species represent each of the three subgenera in Engelman (1859) and Yuncker's (1932) taxonomic treatment of the genus Cuscuta (Table 1). Plant material was field collected from their natural habitats and also obtained from the living collection in different public botanical gardens in Saudi Arabia. Voucher specimens of field collected species are deposited in the herbaria of Biology Department, Faculty of Science, Hail University. The protocol used to obtain mitotic chromosomes from root tips of germinated seeds followed that of Cota and 
Philbrick (1994). Permanent and semi permanent slides were made using Hoyer's fluid (Beek, 1955). The well-spread c-metaphase chromosomes were photographed from temporary preparation at magnifications of $2500 \mathrm{x}$ (Fig. 1). Microscopic observations of chromosomes were made using CarlZiess photomicroscope III at x100.

Chromosome homology was assigned according to similarities in length, morphology and centromere position. Karyotype was constructed for each taxon by arranging the chromosomes in homologous pairs by order of their length and arm ratio as measured from the photographic prints. The chromosome asymmetry based on the position of the centromere was determined using the system developed by Levan et al. (1965). The variation in chromosome length (TCL \& MCL) and chromosome arm ratio (MAR) within the karyotype has been estimated by calculating the standard error (SE) of these parameters. Karyotype asymmetry was also deduced from the ratio between the short arms of the chromosomes and their total length as total form percent (TF \%) as proposed by Huziwara (1962) as follows: [TF\% = sum of short arm length / sum of total chromosome length $\times 100]$. In addition, karyotype asymmetry expressed by the ratio between chromosome arms has been estimated as the intrachromosomal asymmetry index $\left(\mathrm{A}_{1}\right)$ as suggested by Romero- Zarco (1986) as follows:

$$
\mathrm{A}_{1}=1-\sum \frac{\mathrm{b}_{\mathrm{i}}}{\mathrm{B}_{\mathrm{i}}} / \mathrm{n}_{\mathrm{i}}
$$

where $\left(A_{1}\right)$ is the intrachromosomal asymmetry index and ranges from zero to one. The equation is formulated in order to obtain lower values when chromosomes tend to metacentric. $\left(\mathrm{n}_{\mathrm{i}}\right)$ is the number of homologous chromosome pairs. $\left(b_{i}\right)$ is the average length for short arms in every homologous chromosome pair and $\left(\mathrm{B}_{\mathrm{i}}\right)$ is the average length for their long arms. Moreover, karyotype asymmetry due to ratio between the size of different chromosomes has been also estimated as the interchromosomal asymmetry index $\left(\mathrm{A}_{2}\right)$ using Pearson's dispersion coefficient (RomeroZarco,1986).

$$
\mathrm{A}_{2}=\mathrm{S} / \overline{\mathrm{X}}
$$

where, $A_{2}$ is the interchromosomal asymmetry index, and $(\bar{X})$ is mean chromosome length (MCL) and (S) is its standard deviation.

To ascertain patterns of variation between indices and chromosomal variables, an analysis of variance was done using the mean value of five variables of the karyotypes of each taxon i.e. total chromosome length, 
ploidy level, mean chromosome length, mean arm ratio, total form percent and intrachromosomal $\left(\mathrm{A}_{1}\right)$ index. The existence of previous chromosome counts for the studied taxa has been verified in the indexes of plant chromosome numbers by Index to Plant Chromosome Numbers (IPCN) (http://www.tropicos.org/NameSearch.aspx).

\section{Results}

The cytological data for the examined species is summarized in table 1 and their karyotypes are illustrated in Fig. 2. Chromosome number based on basic number of $\mathrm{x}=7$ was found in the majority of the studied species, a diploid number of $2 n=14$ is recorded in five species, whereas a tetraploid number $(2 \mathrm{n}=28)$ is recorded in two species $C$. chinesis and $C$. hyalina. In addition, an octaploid number of $2 \mathrm{n}=56$ was recorded in $C$. campestris. Meanwhile, a number based on $\mathrm{x}=6$ was scored $C$. monogyna, where a polyploidy number of $2 \mathrm{n}=30$ was scored. The chromosomes of the examined species of Cuscuta in Saudi Arabia are generally small (Table 1). Total chromosome length (TCL) varied between the studied species (Fig. 3). Cuscuta planiflora $(\mathrm{TCL}=4.98 \mu \mathrm{m})$ exhibit much shorter chromosomes compared to other species. Meanwhile, longest TCL $(9.52 \mu \mathrm{m})$ have been found in C. campestris. In the remaining species, TCL ranged between 6.54 $\mu \mathrm{m}$ in the $C$. chinesis and $8.44 \mu \mathrm{m}$ in the C. epilinum (Fig. 3). Similarly, shortest MCL was scored in $C$. planiflora $(0.74 \pm 0.009 \mu \mathrm{m})$ and longest MCL in C. campestris $(1.10 \pm 0.18 \mu \mathrm{m})$ (Fig. 4).

The karyotype in the studied species is mostly comprised of metacentric to submetacentric chromosomes as indicated by their mean arm ratio. This ratio ranged between $1.31 \pm 0.19$ in $C$. monogyna and $1.83 \pm 0.22$ in $C$. epilinum (Table 1). The low value of the standard error (SE) for mean arm ratio values indicted low degree of karyotype asymmetry in the studied species. The degree of karyotype asymmetry is also indicated by high values of $\mathrm{TF} \%$ that ranged between $28.33 \%$ in C. planiflora and $29.74 \%$ in $C$. monogyna to $40.54 \%$ in $C$. campestris. Similarly, the A1 value ranged between 0.22 in $C$. planiflora and 0.43 in $C$. palaestina. Also, A2 ranged between 0.15 in $C$. planiflora and 0.2 in $C$. palaestina (Table 1). These values confirm the low karyotype asymmetry as indicated by the values of arm ratio and $\mathrm{TF} \%$.

The plotting of TCL against mean arm ratio (Fig. 5a) distinguish between most of diploid (C. brevistylosa, C. epilinum, C. palaestina and $C$. pedicellate), and the tetraploid species ( $C$. chinesis and $C$. hyalina). In 
particular, this figure clearly distinguished C. monogyna $(2 \mathrm{n}=30, \mathrm{x}=6)$ of subgenus Monogyna, and the diploid C. planiflora of subgenus Cuscuta as well as $C$. campestris $(2 \mathrm{n}=56)$ of subgenus Grammica from the other species. The plotting of total chromosome length against the A1 values (Fig. 5b) also, clearly distinguished C. planiflora, C. monogyna, C. palaestina $(2 \mathrm{n}=14, \mathrm{x}=7)$ and $C$. campestris. The plotting diagram of total chromosome length against the total form percent (Fig. 5c) also, clearly distinguished $C$. planiflora, $C$. chinesis $(2 \mathrm{n}=28, \mathrm{x}=7)$ and $C$. campestris from the other species.

\section{Descussion}

The karyotype of five species in subgenus Cuscuta has been described in the present study viz: $C$. brevistylosa, $C$. epilinum, $C$. palaestina, $C$. pedicelata and $C$. planiflora. The karyotypes of three species viz: $C$. campestris, $C$. chinesis and $C$. hyalina of subgenus Grammica and of $C$. monogyna of subgenus, Monogyna have been described in this study. The diploid number of $2 \mathrm{n}=14$ has been recorded only species belonging to subgenus Cuscuta. This agrees with the earlier records in $C$. planiflora by Pazy and Plitmann (1991). A tetraploid number of $2 \mathrm{n}=28$ was also recorded by Garcia and Castroviejo (2003) in this species. The diploid number $2 \mathrm{n}=14$ for C. brevistylosa, C. epilinum, C. palaestina, and C. pedicelata is recorded for first time in this study. While, the polyploid number $(2 \mathrm{n}=42)$ of $C$. epilinum was recorded by Fogelberg (1938).

In subgenus Grammica, the studied species are uniform in chromosome number $(2 \mathrm{n}=28)$, the only striking variation being found in $C$. campestris, which has $2 \mathrm{n}=56$ (Table 1$)$. The tetraploid chromosome number $(2 \mathrm{n}=28)$ in C. hyalina is recorded for first time in this study. The tetraploid $(2 \mathrm{n}=28)$ and octaploid $(2 \mathrm{n}=56)$ chromosome numbers were recorded in $C$. chinesis by Aryavand (1987), Sampathkumar (1979) and Mesicek and Sojak (1995) respectively. In addition, the chromosome number $(2 n=56)$ for $C$. campestris is similar to the previous counts reported by Aryavand (1987) and Garcia and Castroviejo (2003). Also, the tetraploid number of $2 n=28$ was recorded by Ward (1984) and Khatoon and Ali (1993) for the same species from Mexico and Pakistan respectively. The karyological study of the three species of subgenus Grammica is in agreement with the previous classification of Engelmann (1859) and Yuncker (1932). They placed $C$. chinesis and $C$. hyalina $(2 \mathrm{n}=28)$ in section Eugrammica and $C$. campestris in section Cleistogrammica. Also, the classification of the studied species of 
subgenus Grammica is in agreement with previous results obtained from seed morphology by Abdel Khalik (2006), phylogeny by Costea et al. (2011), pollen and seed characters by Hamed (2005) and molecular characters by Stefanovic et al. (2007).

Striking variation being found in C. monogyna (Subgenera Monogyna), which has $2 \mathrm{n}=30$ based on $\mathrm{x}=6$. This count is similar to the previous recorded by several authors: Pazy and Plitmann (1995, 2002) and Garcia and Castroviejo (2003). Yuncker (1932) split the subgenera Monogyna from the other two subgenera Cuscuta and Grammica on the basis of style characters. Also, the pollen and seed morphology confirms this division (Stefanovic et al., 2002 and Welsh et al., 2010); put the DNA sequence of multiple chloroplast loci does not support this separation (Stefanovic, et al. 2007).

Chromosome number and length variations have been shown in the genus Cuscuta, but closely related species have the same chromosome number and display variability in chromosome size (Fogelberg, 1938). These differences in chromosome size probably indicate genome restructuring and may be used for systematic purpose to distinguish closely related species (Johnson, 1980). In this study, the chromosome length in polyploid taxa was not found to increase or decrease significantly relative to the total chromosome length in diploids. However, the octaploid polyploid C. campestris $(2 \mathrm{n}=56)$ clearly has the longest total chromosome length $(9.52$ $\mu \mathrm{m})$ compared to diploid and other polyploid species of Cuscuta in this study. The MCL of the studied species of Cuscuta is small (Table 1), the shortest MCL was scored in C. planiflora (section Cuscuta) and the largest MCL in C. campestris (section Grammica). The karyotype in the studied species is comprised of metacentric to submetacentric chromosomes as indicated by their mean arm ratio. This ratio ranged between $1.58 \pm 0.13$ in C. chinesis to $1.83 \pm 0.22$ in $C$. epilinum. The degree of karyotype asymmetry in the studied species of Cuscuta is indicated by TF\% that ranged between $32.33 \%$ in C. planiflora and $40.54 \%$ in C. campestris (Table 2).

The TF\% in the studied species of subgenus Cuscuta ranged between 28.33 in $C$. planiflora to $38.92 \%$ in $C$. pedicelata. The delimitation of $C$. pedicelata from the other species of subgenus Cuscuta by the high value of $\mathrm{TF} \%$ is in agreement with previous classification that placed $C$. pedicelata in section Epistigma and the remaining species in section Cuscuta based on variation in morphological traits, and seed morphology, as well as molecular 
and micromorphological data (Yuncker, 1932; Sampathkumar and Ayyangar (1978); Stefanovic, et al., 2002; Abdel Khalik, 2006; Costea, et al. 2006a, b, c, d, 2008 and Costea and Stefanovic, 2009b). Also, in subgenus Grammica the C. campestris $(\mathrm{TF} \%=40.54 \%)$ was placed in section Cleistogrammica while the $C$. chinesis and $C$. hyalina $(\mathrm{TF} \%=37.87$ and 36.44) were placed in section Eugrammica based on exomorphological traits, seed morphology and phylogenetic (Yuncker, 1932; Abdel Khalik, 2006; Garcia and Martin, 2007; Stefanovic et al., 2007).

The subgenus Monogyna was split from the subgenus Cuscuta on the basis of the single style (Yuncker, 1932). The chromosome number of $C$. monogyna $(2 \mathrm{n}=30, \mathrm{x}=6)$ was found to be also unique in the genus Cuscuta $(\mathrm{x}=7)$. In this study, most of the karyotype analysis confirmed this separation and are in congruent with the results of Stefanovic et al. (2002) and Abdel Khalik (2006) based on molecular and seed morphology characters.

\section{Taxonomic significance of karyotype characters in Cuscuta}

The division of the genus Cuscuta into the three subgenera Cuscuta, Grammica and Monogyna following Engelmann (1859) and Yuncker (1932). This arrangement has been largely confirmed by phylogenetic studies, the numerous sections and subsections created by Yuncker have been shown to be polyphyletic (Garcia and Martin 2007; Stefanovic et al., 2007). At the species level, the systematic of Cuscuta is currently undergoing major taxonomic revisions through studies aimed at understanding the evolutionary relationships, specification and biogeography by using various molecular, morphological, and micromorphological data (Costea, et al. 2006a, b, c, d, 2008a; Costea and Stefanovic 2009b). It is clear that variation in chromosome number and karyotype criteria is important for future taxonomic revisions at the species level.

\section{Acknowledgement}

Thanks are due to Dr. Abdelfattah Badr, Professor of Genetics and Biosystematics, Botany Department, Faculty of Science, Helwan University for the final revision of the present article. 
Table 1. A list of studied species, assigned to species subgenera and a summary of the karyotype features.

\begin{tabular}{|c|c|c|c|c|c|c|c|c|c|c|c|c|c|}
\hline \multirow{2}{*}{ No. } & \multirow{2}{*}{ Taxa } & \multirow{2}{*}{$x$} & \multirow{2}{*}{$2 n$} & \multirow{2}{*}{$\begin{array}{l}\text { TCL } \\
(\mu \mathrm{m})\end{array}$} & \multirow{2}{*}{$\begin{array}{l}\text { MCL } \\
\pm \mathrm{SE} \\
(\mu \mathrm{m}) \\
\end{array}$} & \multirow{2}{*}{$\begin{array}{c}\text { MAR } \\
\pm \text { SE } \\
(r \text {-value }) \\
\end{array}$} & \multirow{2}{*}{$\begin{array}{c}\text { TF } \\
\%\end{array}$} & \multirow{2}{*}{$\mathbf{A}_{1}$} & \multirow{2}{*}{$\mathbf{A}_{2}$} & \multicolumn{3}{|c|}{ Chr. Type } & \multirow{2}{*}{$\begin{array}{c}\text { Previous } \\
\text { Chr. } \\
\text { count } \\
\end{array}$} \\
\hline & & & & & & & & & & $\mathbf{m}$ & sm & st & \\
\hline \multicolumn{14}{|c|}{ I- Subgenus: Cuscuta (Eucuscuta) } \\
\hline 1 & $\begin{array}{l}\text { C. brevistylosa } \\
\text { R.Br. }\end{array}$ & 7 & $14^{*}$ & 8.30 & $\begin{array}{c}0.93 \\
\pm 0.13\end{array}$ & $\begin{array}{c}1.63 \\
\pm 0.12\end{array}$ & 33.67 & 0.36 & 0.16 & 3 & 4 & - & - \\
\hline 2 & $\begin{array}{l}\text { C. epilinum } \\
\text { Weihe }\end{array}$ & 7 & 14 & 8.44 & $\begin{array}{c}0.95 \\
\pm 0.15\end{array}$ & $\begin{array}{c}1.83 \\
\pm 0.22\end{array}$ & 34.88 & 0.31 & 0.19 & 3 & 4 & - & $\begin{array}{l}14,16,28, \\
30,32,42\end{array}$ \\
\hline 3 & $\begin{array}{l}\text { C. palaestina } \\
\text { Boiss. }\end{array}$ & 7 & $14^{*}$ & 8.03 & $\begin{array}{c}0.91 \\
\pm 0.12 \\
\end{array}$ & $\begin{array}{c}1.61 \\
\pm 0.17 \\
\end{array}$ & 34.32 & 0.43 & 0.22 & 4 & 3 & -- & - \\
\hline 4 & $\begin{array}{l}\text { C. pedicellata } \\
\text { Ledeb. }\end{array}$ & 7 & $14 *$ & 7.99 & $\begin{array}{c}0.87 \\
\pm 0.10\end{array}$ & $\begin{array}{c}1.81 \\
\pm 0.20\end{array}$ & 38.92 & 0.37 & 0.19 & 2 & 4 & 1 & - \\
\hline 5 & $\begin{array}{l}\text { C. planiflora } \\
\text { Ten. }\end{array}$ & 7 & 14 & 4.98 & $\begin{array}{c}0.74 \\
\pm 0.09 \\
\end{array}$ & $\begin{array}{c}1.64 \\
\pm 0.19 \\
\end{array}$ & 28.33 & 0.22 & 0.15 & 3 & 4 & -- & $14,26,28$ \\
\hline \multicolumn{14}{|c|}{ II- Subgenus: Grammica } \\
\hline 6 & $\begin{array}{l}\text { C. campestris } \\
\text { Yuncker }\end{array}$ & 7 & 56 & 9.52 & $\begin{array}{c}1.10 \\
\pm 0.18 \\
\end{array}$ & $\begin{array}{c}1.71 \\
\pm 0.24 \\
\end{array}$ & 40.54 & 0.41 & 0.21 & 1 & 5 & 1 & 28,56 \\
\hline 7 & $\begin{array}{l}\text { C. chinesis } \\
\text { Lam. }\end{array}$ & 7 & 28 & 6.54 & $\begin{array}{c}0.79 \\
\pm 0.09 \\
\end{array}$ & $\begin{array}{c}1.58 \\
\pm 0.19 \\
\end{array}$ & 37.87 & 0.33 & 0.16 & 3 & 3 & 1 & $\begin{array}{c}28,32,56, \\
60\end{array}$ \\
\hline 8 & $\begin{array}{l}\text { C. hyalina } \\
\text { Roth. }\end{array}$ & 7 & $28 *$ & 7.11 & $\begin{array}{c}0.82 \\
\pm 0.08 \\
\end{array}$ & $\begin{array}{c}1.62 \\
\pm 0.16 \\
\end{array}$ & 36.44 & 0.34 & 0.21 & 1 & 6 & - & - \\
\hline \multicolumn{14}{|c|}{ III- Subgenus: Monogyna (Monogynella) } \\
\hline 9 & $\begin{array}{l}\text { C. monogyna } \\
\text { Vahl. }\end{array}$ & 6 & 30 & 7.24 & $\begin{array}{c}0.84 \\
\pm 0.09 \\
\end{array}$ & $\begin{array}{c}1.31 \\
\pm 0.19 \\
\end{array}$ & 29.74 & 0.24 & 0.19 & 4 & 2 & - & 28,30 \\
\hline \multicolumn{14}{|c|}{$\begin{array}{l}\mathbf{A}_{1}=\text { Intrachromosomal asymmetry index. } \\
\mathbf{A}_{2}=\text { Interchromosomal asymmetry index. } \\
\text { Chr. = Chromosome. } \\
\mathbf{m}=\text { Metacentric region chromosome. } \\
\text { sm = Submetacentric chromosome. } \\
\text { st = Subtelocentric chromosome. } \\
{ }^{*}=\text { New chromosome record. }\end{array}$} \\
\hline
\end{tabular}



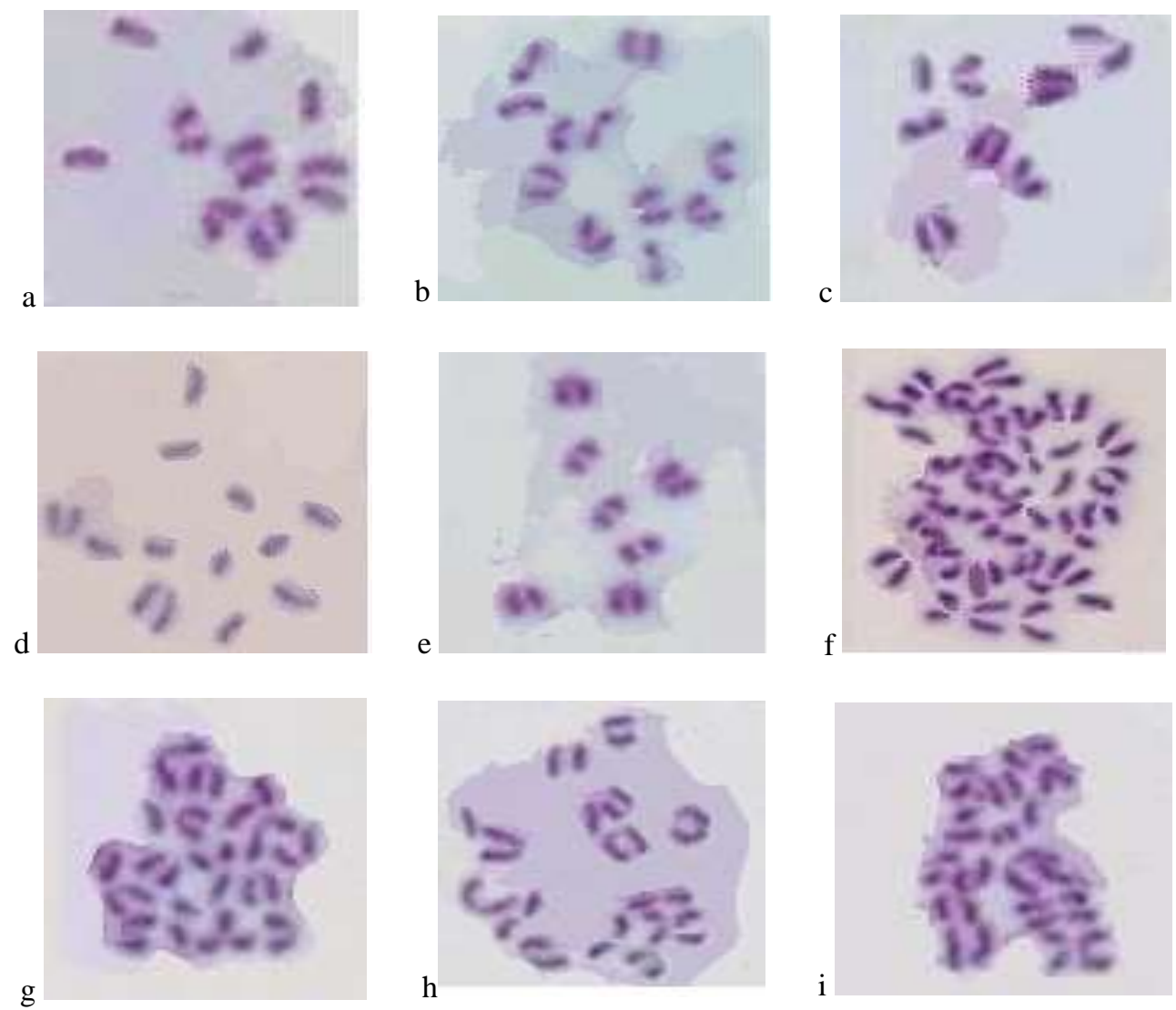

Fig. 1. Micrographs of the somatic metaphase chromosomes of nine Saudi Arabian species of the genus Cuscuta: a-C. brevistylosa $(2 \mathrm{n}=2 \mathrm{x}=$ $14)$, b- C. epilinum $(2 \mathrm{n}=2 \mathrm{x}=14)$, c- C. palaestina $(2 \mathrm{n}=2 \mathrm{x}=14)$, d- C. pedicellata $(2 \mathrm{n}=2 \mathrm{x}=14)$, e- $C$. planiflora $(2 \mathrm{n}=2 \mathrm{x}=14), \mathrm{f}-$ C. campestris $(2 \mathrm{n}=8 \mathrm{x}=56), \mathrm{g}-C$. chinesis $(2 \mathrm{n}=4 \mathrm{x}=28)$, h- $C$. hyalina $(2 \mathrm{n}=4 \mathrm{x}=28)$, i- C. monogyna $(2 \mathrm{n}=4 \mathrm{x}=30)$. (Scale bars $=10 \mu \mathrm{m})$. 


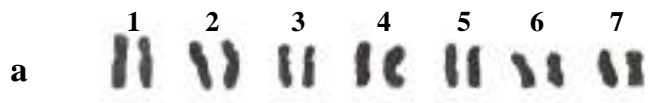

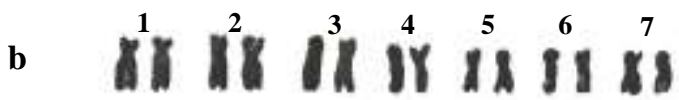

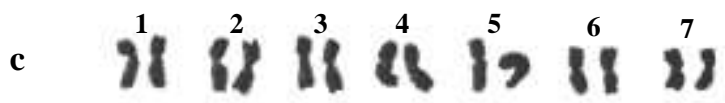

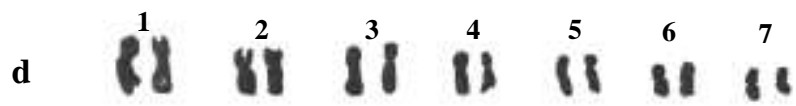

e it is $\quad \begin{array}{cccccc}1 & 4 & 5 & 6 & 7 \\ \text { it } & \text { is } & \text { it }\end{array}$

$\mathbf{f}$

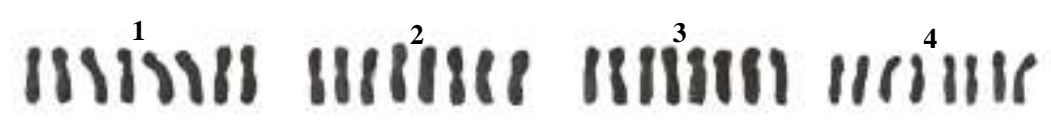

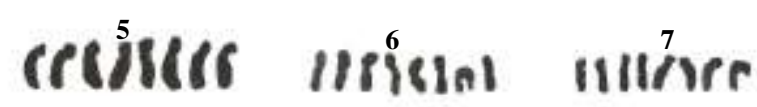

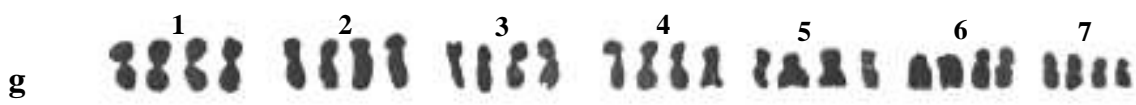

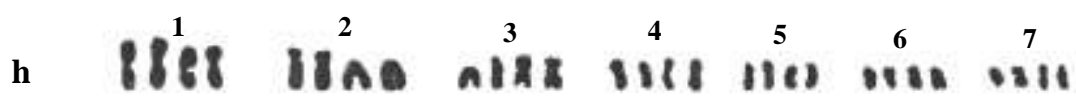

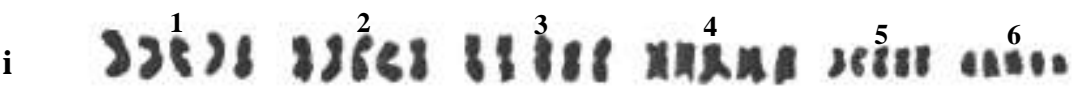

Fig. 2. Karyotypes of 9 species of Cuscuta L. a: C. brevistylosa, b: C. epilinum, c: C. palaestina, d: C. pedicellata, e: C. planiflora, f: $C$. campestris, g: $C$. chinesis, h: $C$. hyalina and i: C. monogyna. $\mathrm{Bar}=$ $2 \mu \mathrm{m}$. 


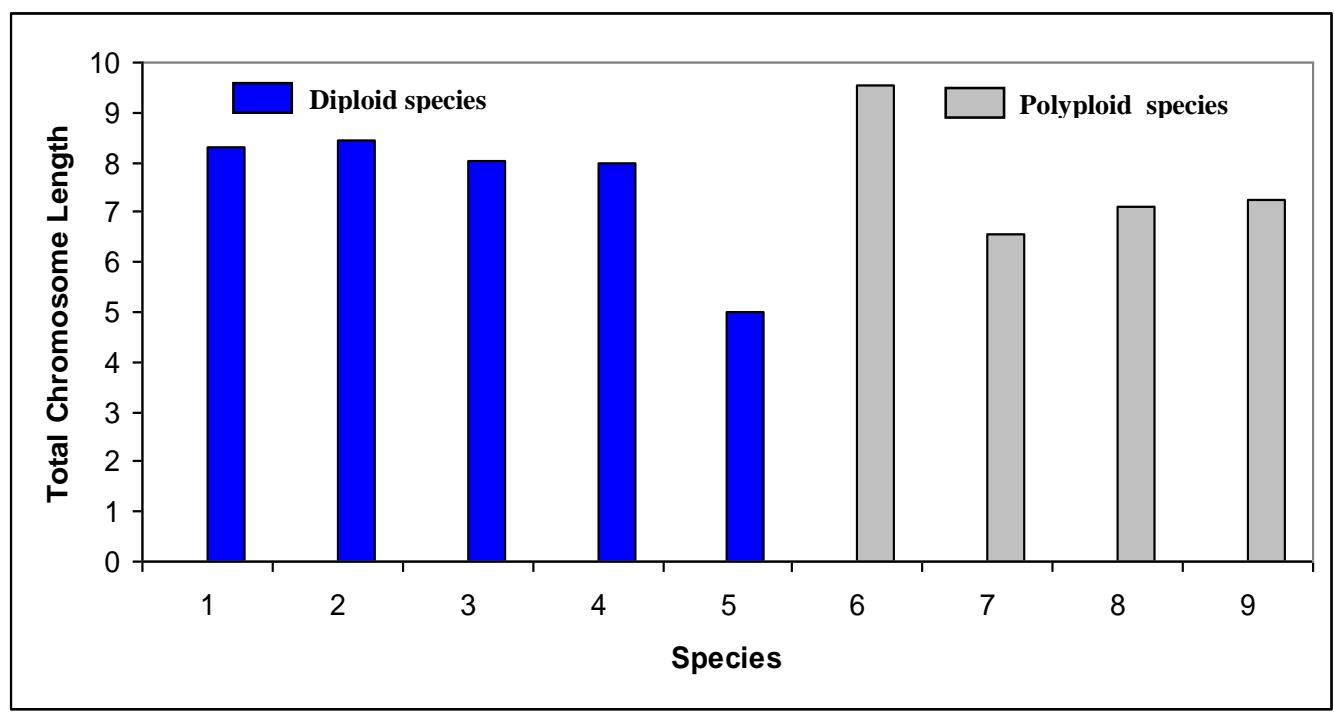

Fig. 3. Histogram showing the total chromosome length per species. (See Table 1 for species name).

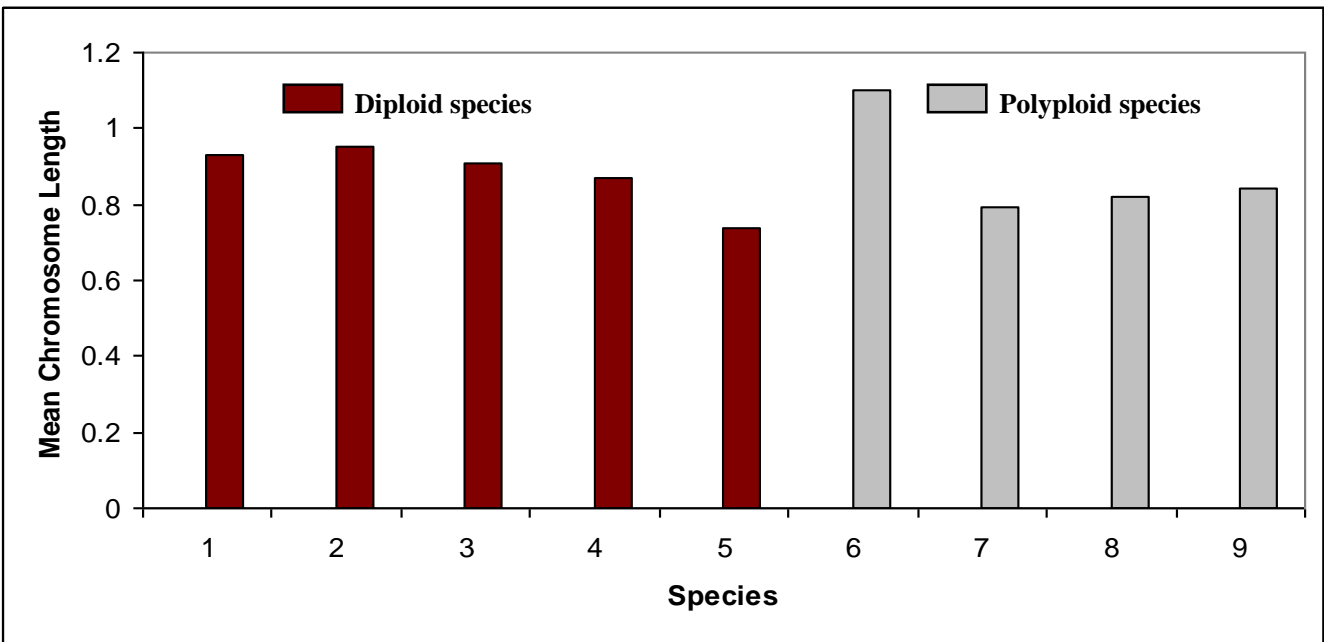

Fig. 4. Histogram showing the mean chromosome length per species. (See Table 1 for species name). 

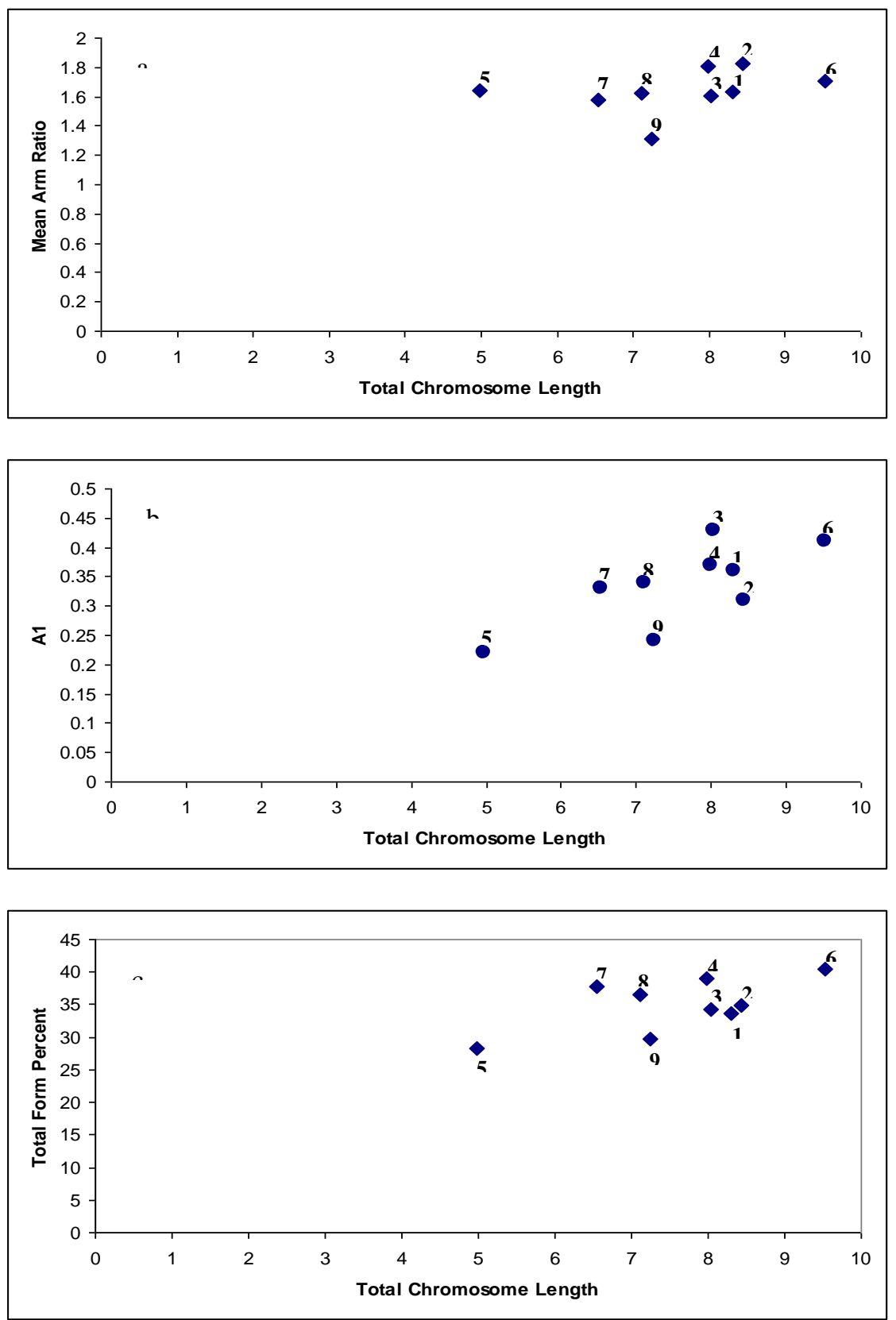

Fig. 5. The relationship between chromosome length and each of mean chromosome arm ratio (a), A1 values (b) and total form percent (c). (See Table 1 for species name). 


\section{References}

http://www.tropicos.org/NameSearch.aspx.

Abdel Khalik, K. N., 2006. Seed morphology of Cuscuta L. (Convolvulaceae) in Egypt and its systematic significance. Feddes Repertorium. 117(3-4):217-224.

Aryavand, A., 1987. The chromosome numbers of some Cuscuta L. (Cuscutaceae) species from Isfahan, Iran. Journal of Botany. 3:177182.

Austin, D. F., 1975. Convolvulaceae. In: Woodson, R.E. (ed.) Flora of Panama. Ann. Missouri Bot. Gard., 62:157-224.

Badr, A. and Elkington, T., 1978. Variation in Giesma C-banded and flurochromes banded karyotypes and relationships in Allium subgenus Molium. Plant Syst. Evol., 18: 23-35.

Badr, A. and El-Kholy, M. A., 1986. Chromosomal studies in the Egyptian flora II. Karyotype studies in Plantago L. Cytologia, 52:725-731.

Badr, A. and Sharawy, S. M., 2007. Karyotype analysis and systematic relationships in the Egyptian Astragalus L. (Fabaceae). Inter. J. Bot. 3(2):147-159.

Beeks, R. M., 1955. Improvements in squash technique for plant chromosomes. Aliso, 3:131-134.

Bentham, G. and Hooker, J. D., 1862. Genera Plantarum 3 vol. London

Bessey, C. E., 1915. The phylogenetic taxonomy of flowering plants. Ann. Missouri Bot. Gard. 2:64-109.

Braukmann, T., Kuzmina, M. and Stefanovic, S., 2013. Plastid genome evolution across the genus Cuscuta (Convolvulaceae): two clades within subgenus Grammica exhibit extensive gene loss. Journal of Experimental Botany. 99(9):1513-23.

Collenette, I.S. 1999: Wild flowers of Saudi Arabia. 799 pp. National commission for wildlife conservation, Riyadh.

Core, E. L., 1955. Plant Taxonomy. Englewood Cliffs, NJ.

Costea, M., and Stefanović, S., 2009. Molecular phylogeny of Cuscuta californica complex (Convolvulaceae) and a new species from New Mexico and Trans-Pecos. Systematic Botany. 34: 570-579.

Costea, M. and Tardif, F. J., 2006. Biology of Canadian weeds. Cuscuta campestris Yuncker, C. gronovii Willd. ex Schult., C. umbrosa Beyr. ex Hook., C. epithymum (L.) L. and C. epilinum Weihe. Canadian Journal of Plant Sciences. 86: 293-316. 
Costea, M., Nesom, G. L. and Stefanović, S., 2006a. Taxonomy of the Cuscuta pentagona complex (Convolvulaceae) in North America. Sida. 22: 151-175.

Costea, M., Nesom, G. L., and Stefanović, S., 2006b. Taxonomy of the Cuscuta indecora (Convolvulaceae) complex in North America. Sida. 22: 209-225.

Costea, M., Nesom, G. L., and Stefanović, S., 2006c. Taxonomy of the Cuscuta salina californica complex (Convolvulaceae). Sida. 22: 176-195.

Costea M., Nesom G. L. and Stefanovic' S., 2006d: Taxonomy of the Cuscuta salina-californica complex (Convolvulaceae). Sida 22:176195

Costea, M., Aiston, F., and Stefanović, S., 2008. Species delimitation, phylogenetic relationships and two new species in the Cuscuta gracillima complex (Convolvulaceae). Botany. 86: 670-681.

Costea, M., Aiston, F., and Stefanović, S., 2009b. Molecular Phylogeny of the Cuscuta californica Complex (Convolvulaceae) and a New Species from New Mexico and Trans-Pecos. Systematic Botany. 34(3):570-579.

Costea, M., García, I. R., and Stefanović, S., 2011. 'Horned'dodders: phylogenetic relationships and two new species within Cuscuta chapalana complex (Convolvulaceae). Botany, accepted.

Cota, J. H. and Philbrick, C. T., 1994. Chromosome number variation and polyploidy in the genus Echinocereus (Cactaceae). Amer. J. Bot. 81:1054-1062.

Cronquist, A. J., 1968. Evolution of flowering plants. Houghton Miffin Co., Boston, USA.

Dawson, J. H., Musselman, L. J., Wolswinkel, P. and Dorr, I., 1994. Biology and control of Cuscuta. Rev. Weed Sci. 6:265-317.

El-Shazly, H. H. and Abou-El-eanin, M. M., 1999. Chromosomal criteria of some Sesbania species and their taxonomic inferences. Bull. Fac. Assiut Univ. 28(2):123-132.

Engelmann, G., 1859. Systematic arrangement of the species of the genus Cuscuta, with critical remarks on old species and descriptions of new ones. Tran. Acad. Sci. St. Louis. 1: 453-523

Engler, A., 1964. Syllabus der Pflanzen-Familien Vol.2, 12th Ed., revised by H. Melchior Gebrüder, Borntraeger, Berlin. 
Fernandez, J., Nava, H., Vera, M., Alvareg, M., Diaz, T., Fernandez, M. I., Fernandez M. C. and Gutierrez, M., 1993. Chromosome numbers and geographic distribution of Ulex gallii and $U$. minor (Leguminosae). Bot. J. Linn. Soc. 122: 43-49.

Fogelberg, S. O. 1938: The cytology of Cuscuta. Bull. Torrey Bot. Club. 65:631-645.

Garcia, M. A. and Castroviejo, S., 2003. Estudios citotaxonómicos en las especies ibéricas del ge'nero Cuscuta (Convolvulaceae). Annals Jard. Bot. Madrid. 60:33-44.

Garcia, M. A. and Martin, M. P., 2007. Phylogeny of Cuscuta subgenus Cuscuta (Convolvulaceae) based on nrDNA ITS and chloroplast trnL intron sequences. Sys. Bot. 32:899-916.

Hadač, E. and Chrtek, J. 1970. Notes on taxonomy of Cuscutaceae. Folia Geobotanica and Phytotaxonomica. Praha. 5: 443-5.

Hamed, K. A. 2005. Pollen and seed characters of Certain Cuscuta species growing in Egypt with a reference to a taxonomic treatment of the genus. Int. J. Agri. Biol. 7(3): 325-332.

Hutchinson, J., 1959. Families of Flowering Plants. I. Dicotyledons. Oxford University Press, N.Y., U.S.A.

Hutchinson, J.M. and F.M. Ashton, 1979. Effects of desiccation and scarification on the permeability and structure of the seed coat of Cuscuta campestris. American J. Bot. 66: 40-6.

Hunziker, A. T. 1950. Las especies de Cuscuta (Convolvulaceae) de Argentina y Uruguay. Revista de la Facultad de Ciencias Exactas, F1'sicas y Naturales. 13: 178-251.

Huziwara, Y., 1962. Karyotype analysis in some genera of Compositae VIII. Further studies on the chromosomes of Aster. Am. J. Bot. 49:116119.

Jackson, R. C. 1984. Chromosome pairing in species and hybrids. In W.F. Grant (Ed.), Plant biosystematics, 67-86. Academic Press, Toronto, Ontario, Canada.

Jianquan, L., Tingnong, H., Shilong, C. and Anmin, L., 2001. Karyomorphology of Biebersteinia Stephan (Geraniaceae) and its systematic and taxonomic significance. Bot. Bull. Acad. Sin. 42:6166.

Johnson M.A. 1980. Further cytological inestigations in Mammillaria prolifera and other Mammillaria species. Cactus Succul. J. (Great Britian), 42:43-47. 
Khatoon, S. and Ali, S.I. 1993. Chromosome Atlas of the Angiosperms of Pakistan. Department of Botany, BCC\&T Press, University of Karachi, pp. 232.

Kujit, J., 1969. The Biology of Parasitic Flowering Plants. University of California Press. USA.

Levan, A., K. Fredga and Sanders, A. A. 1965. Nomenclature for centromeric position on chromosomes. Hereditas. 52:201-220.

Mabberley, D. J. 1987. Plant-Book-a portable dictionary of the higher plants. Cambridge University Press, Cambridge.p.100.

Mandaville, J. P., 1990. Flora of Eastern Saudi Arabia. Kegan Paul, London and NCWCD, Riyadh.

McNeal, J. R., 2005. Systematics and plastid genome evolution in the parasitic plant genus Cuscuta (dodder). Ph.D. dissertation, Pennsylvania State University, University Park, Pennsylvania, USA.

Mesicek, J. and Sojak, J. 1995. Chromosome numbers of Mongolian angisperms. II Folia Geobot. Phytotax. 30: 445-453.

Migahid, A.M., 1989. Flora of Saudi Arabia. King Saud University Libraries. 2: 173-178.

Moore, D. M. 1978. The Chromosomes and Plant Taxonomy. In: Street, H.E. (Ed.) Essays in Plant Taxonomy. Acad. Press, London, New York, pp. 39-56.

Pazy, B. and Plitmann, U. 1991. Unusual chromosome separation in meiosis of Cuscuta L. Genome. 34:533-536.

Pazy, B. and Plitmann, U. 1995. Chromosome divergence in the genus Cuscuta and its systematic implications. Caryologia. 48:173-180.

Pazy, B. and Plitmann, U. 2002. New perspectives on the mechanisms of chromosome evolution in parasitic flowering plants. Bot. J. Linn. Soc. 138(1): 117-122.

Peter, A., 1897. Convolvulaceae. Pp. 375-377 - in Engler A.\& Prantl K. (eds.), Die Natürlichen Pflanzenfamilien, 4. - Leipzig.

Parker, C. and Riches, C. R., 1993. Parasitic weeds of the world. Biology and control. Wallingford: CAB International.

Press, M. C. and Phoenix G. K., 2005. Impacts of parasitic plants on natural communities. New Phytologist. 166: 737-751.

Romero-Zarco, C.R., 1986. A new method for estimating karyotype asymmetry. Taxon. 35: 526-530.

Sampathkumar, R., 1979. Karyomorphological studies on some South Indian Convolvulaceae. Cytologia. 44: 275-286. 
Sharawy, S.M., 2008. Chromosomal Criteria and Taxonomic Relationships in the Egyptian Erodium L'Hèr. (Geraniaceae). Taeckholmia. 28: 131-145.

Stebbins, G.L., 1956. Cytogenetics and evolution of the grass family. American Journal of Botany. 43: 890-905.

Stefanovic, S., Krueger, L. and Olmstead, R. G., 2002. Monophyly of the Convolvulaceae and circumscription of their major lineages based on DNA sequences of multiple chloroplast loci. Amer. J. Bot. 89(9): 1510-1522.

Stefanović, S., Kuzmina, M. and Costea, M., 2007. Delimitation of major lineages within Cuscuta subgenus Grammica (dodders; Convolvulaceae) using plastid and nuclear DNA sequences. Am. J. Bot. 94: 568-589.

Takhtajan, A.L., 1980. Outline of the classification of flowering plants (Magnoliophyta). Bot. Rev. 46: 296-359.

van der Kooij, T. A. W., Krause, K., Dorr, I.and Krupinska, K.. 2000. Molecular, functional and ultrastructural characterization of plastids from six species of the parasitic flowering plant genus Cuscuta. Planta. 210: 701-707.

Ward, D. E., 1984. Chromosome counts from New Mexico and Mexico. Phytologia 56: 55-60.

Willis, J.C., 1973. A Dictionary of the Flowering Plants and Ferns (8th ed.) Cambridge University Press.

Welsh, M., S. Stefanović, and M. Costea. 2010. Pollen evolution and its taxonomic significance in Cuscuta (dodders, Convolvulaceae). Plant Syst. Evol. 285: 83-101.

Yuncker, T. G. 1932. The genus Cuscuta. - Mem. Torrey Bot. Club. 18: 113-331. 